\title{
Experimental Study of Electrode Structuring using Nanosecond Laser for Enhanced Battery Performance
}

\author{
리튬이온 배터리 성능 향상을 위한 나노초 레이저를 이용한 \\ 전극의 구조화 실험적 연구 \\ Dongkyu Park* and Dongkyoung Lee*, ${ }^{*}$ \\ *Department of Mechanical and Automotive Engineering, Kongju National University, \\ Cheonan, 31080, Korea
}

†Corresponding author : 1dkkinka@gmail.com

(Received June 3, 2020 ; Revised July 6, 2020 ; Accepted July 14, 2020)

\begin{abstract}
Currently, alternative energy sources are attracting attention owing to environmental pollution and the depletion of fossil fuels. Lithium-ion batteries have a light weight, high energy density, high power density, and long cycle life, making them attractive alternative energy sources. Numerous studies have been conducted on high-performance batteries. However, most studies have focused on improving active material characteristics. Thus, there is a lack of research on battery performance enhancement through the improvement of the battery manufacturing process. In this study, we performed electrode structuring using a nanosecond laser in the power range of $1 \mathrm{~W}$ to $19 \mathrm{~W}$ ( $2 \mathrm{~W}$ intervals). The geometric changes after laser structuring were observed using a scanning electron microscope, and the electrode geometries were classified and measured in terms of ablation width and depth. The aspect ratio, removal amount, and removal rate of the active material were analyzed after laser structuring. A maximum aspect ratio of 0.77 was achieved. Additionally, the removal amount and removal rate of the active material increased with the increase in laser power. Therefore, we concluded that electrode geometry can be controlled using a nanosecond laser.
\end{abstract}

Key Words : Lithium-ion battery; Laser structuring; Nanosecond laser; Aspect ratio

\section{Introduction}

Lithium-ion batteries have attracted attention as a solution for environmental pollution and fossil fuel depletion due to their benefits of light weight, high energy density, high power density, and long cycle life. A lithium-ion battery consists of a cathode, an anode, an electrolyte, and a separator. In particular, the cathode and anode are important elements that determine the energy and power densities of the battery ${ }^{1-2)}$. Therefore, many studies have been conducted to improve battery performance in the electrode manufacturing process and to address the existing problems with the battery processing process. As for studies related to battery performance improvement, $\mathrm{Li}$ et $\mathrm{al}^{3)}$ improved the power density by forming the coating layer of carbon and $\mathrm{GdPO} 4$ on $\mathrm{LiFePO}_{4}$ and thereby increasing the ion diffusion rate. Lee et al. ${ }^{4}$ cut electrodes using a laser to complement the shortcomings of the existing electrode cutting process. They compared cutting characteristics between compressed and uncompressed electrodes, and reported that compressed electrodes are more favorable for obtaining a uniform cutting width when electrodes are cut using a laser.

In recent years, many processes, such as cutting, welding, heat treatment, and surface processing, have been successfully replaced with laser-9). Laser is used for non-contact processing. They require low maintenance cost and can reduce the contamination of workpieces. They also enable micro-scale processing and can easily process complex geometry. Moreover, laser can process sensitive materials, such as plastics, glass, and thin films, with minimal deformation ${ }^{10,13)}$. 
In this study, electrode structuring was performed using a laser to improve the power density of the lithium-ion battery. A problem with the existing electrode structure is that applying a thick coat of an active material to increase the energy density decreases the power density and, conversely, applying a thin coat of the active material to increase the power density decreases the energy density and accelerates the discharge of the battery. To overcome these limitations of the electrode structure, three-dimensional electrodes have been proposed. In a previous study, laser structuring was performed using femtosecond-laser, picosecond-laser, and nanosecond- laser pulses on $\mathrm{LiFePO}_{4}$ electrodes, and the formed grooves and battery performances were compared ${ }^{14)}$. As the pulse duration was shorter, the aspect ratio of the structured electrode increased. As the aspect ratio increased, an increase in power density was reported in the battery performance test. In a previous study, however, only the influence of the pulse duration was observed and information on changes according to the laser power was not provided. In addition, the femtosecond laser, which has a small thermal effect and is favorable for selectively removing materials, is still an expensive device $^{10)}$. Therefore, this study was conducted as a basic study to fabricate a high-power battery by forming geometric shapes on the electrode surface using the nanosecond laser, which requires lower investment cost than the femtosecond laser. Using nanosecond laser, the influence of the laser power was observed through the ablation width, ablation depth, and aspect ratio. In addition, the removal amount and the removal rate of active material were analyzed.

\section{Experimental Materials and Methods}

\subsection{Material}

Fig. 1 shows the photograph of the electrode used in the experiment and the schematic of its cut surface. The electrode was fabricated in a dry room where the room
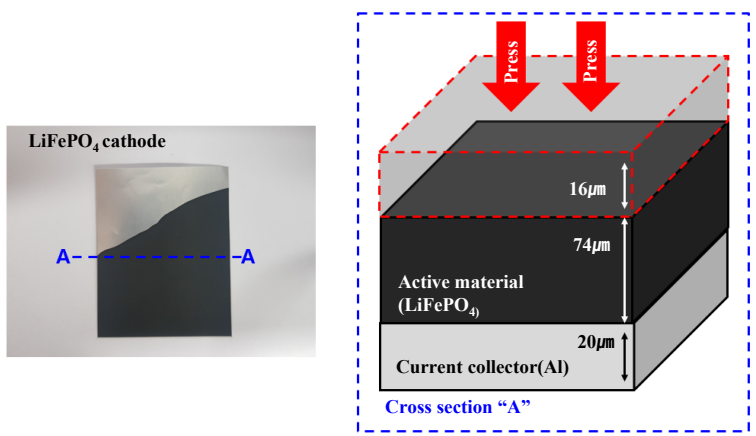

Fig. 1 Image of electrode used for the experiments

Table 1 Information of electrode used for the experiments

\begin{tabular}{|c|c|}
\hline Classification & Information \\
\hline Structure & One-side sandwich \\
\hline Active material & $\mathrm{LiFePO}_{4}(8)$ \\
\hline Binder & Polyvinylidene fluoride (1) $^{\text {Super } \mathrm{P}(1)}$ \\
\hline Conducting agent & $90 \mu \mathrm{m} \rightarrow 74 \mu \mathrm{m}$ \\
\hline Active electrode thickness & Aluminum Foil \\
\hline Current collector & $20 \mu \mathrm{m}$ \\
\hline Current collector thickness & \\
\hline
\end{tabular}

temperature was $20^{\circ} \mathrm{C}$ and the dew point was maintained at $-40^{\circ} \mathrm{C}$ or less. Table 1 shows detailed information on the electrode. The slurry used for the electrode was prepared by mixing $\mathrm{LiFePO}_{4}$ (active material), polyvinylidene fluoride (binder), and Super P (conducting agent) at a mass fraction ratio of $8: 1: 1$. The prepared slurry with a thickness of $90 \mu \mathrm{m}$ was coated only on one side on $20 \mu \mathrm{m}$ aluminum foil to make an electrode with the one-side sandwich structure. It was subjected to primary drying in an oven at $120^{\circ} \mathrm{C}$ for two hours and the electrode was compressed by performing calendaring to create an electrode with a total thickness of $94 \mu \mathrm{m}$. Finally, secondary drying was performed at $120^{\circ} \mathrm{C}$ for 24 hours.

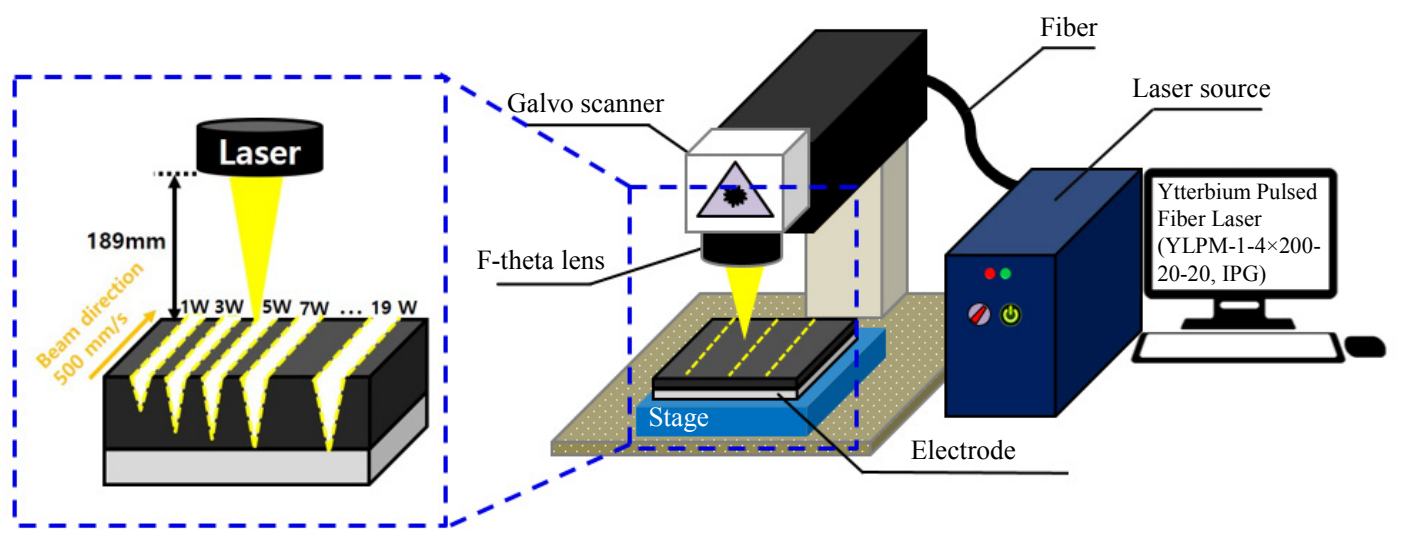

Fig. 2 Schematic of the nanosecond laser for laser structuring of electrode 
Table 2 Laser parameters used for the experiments

\begin{tabular}{|c|c|}
\hline Parameters & Specifications \\
\hline Average power & $1 \sim 19 \mathrm{~W}$ \\
\hline Mode & Pulsed laser \\
\hline Wavelength & $1064 \mathrm{~nm}$ \\
\hline Pulse duration & $4 \mathrm{~ns}$ \\
\hline Pulse repetition rate & $500 \mathrm{kHz}$ \\
\hline Scanning speed & $500 \mathrm{~mm} / \mathrm{s}$ \\
\hline Focal length & $189 \mathrm{~mm}$ \\
\hline Spot size & Approx. $30 \mu \mathrm{m}$ \\
\hline Beam quality (M2) & 1.5 \\
\hline
\end{tabular}

\subsection{Laser processing}

The ytterbium pulsed fiber laser (YLPM-1-4x200-20-20, IPG) used for electrode structuring had a maximum average power of $20 \mathrm{~W}$ and a wavelength of $1,064 \mathrm{~nm}$. It could also change the pulse duration from 4 to $200 \mathrm{~ns}$. Its $\mathrm{M}^{2}$ value was 1.5 . The experiment was simplified by only changing the average power among various laser processing parameters. The average power was increased by $2 \mathrm{~W}$ from 1 to $19 \mathrm{~W}$.

\subsection{Analysis method}

Fig. 3 shows a scanning electron microscope (SEM) image captured after laser irradiation on the electrode. The ablation top width $\left(W_{t o p}\right)$, ablation bottom width $\left(W_{b o t}\right)$, and ablation depth (D) were defined to analyze the geometric change of the electrode. The ablation top width is the top width of the groove formed when the active material was removed by laser processing on the electrode. The ablation bottom width is the bottom width of the groove formed when the active material was removed by laser processing on the electrode, and the ablation depth is the depth of the groove formed when the active material was removed by laser process-

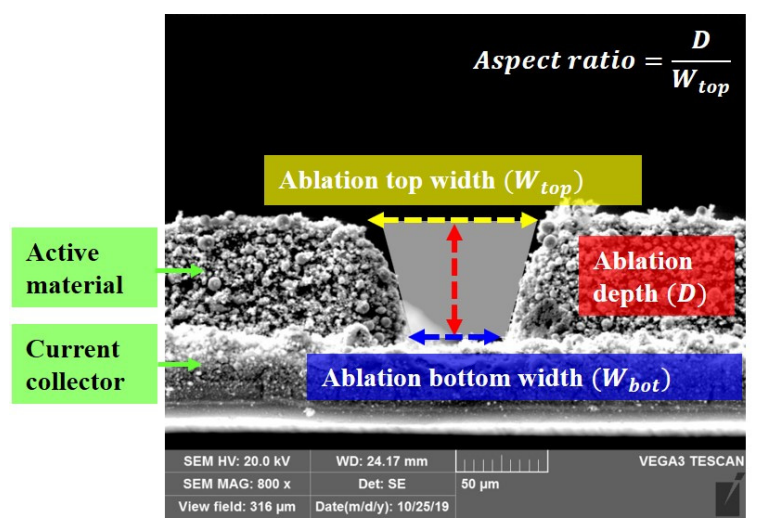

Fig. 3 Measurement method of the ablation top width, ablation bottom width, ablation depth ing on the electrode. The aspect ratio was calculated using the measured ablation top width and ablation depth.

\section{Experiment Results and Discussion}

\subsection{Ablation width and Ablation depth}

Fig. 4 shows the SEM images of the electrode after laser processing. As can be seen from the figure, as the laser power increased, both the ablation width and ablation depth increased. The top view (Fig. 4(a)) shows that the depth of the groove generated in the active material layer increased and reached the surface of the current collector as the laser power increased, but the $\mathrm{Al}$ foil with the active material completely removed was not observed. Fig. 5 shows the ablation width and ablation depth measurements according to the laser power. Fig. 5(a) shows that the ablation top width linearly increased as the laser power increased. The largest width of approximately $102 \mu \mathrm{m}$ was observed when the power was $19 \mathrm{~W}$. The ablation bottom width, on the other hand, was not formed until $13 \mathrm{~W}$, and it was formed from $15 \mathrm{~W}$ as most of the active material was removed. Fig. 5(b) shows that the ablation depth linearly increased as the laser power increased. It increased more rapidly compared to the ablation width, but it no longer increased after the coated active material was removed to the surface of the current collector. For a more accurate comparison, the trend lines and correlation coefficients $(\gamma)$ of the ablation width and ablation depth were calculated through regression analysis. As the ablation depth no longer increased due to the complete removal of the active material from $13 \mathrm{~W}$ of the laser power, only the data before the complete removal of the active material were used for the regression analysis. As shown in Fig. 5, the trend line slope of the ablation width was 5.1643 and that of the ablation depth was 5.9063, indicating that the slope of the ablation depth increased more rapidly.

\subsection{Aspect ratio}

Fig. 6(a) shows the aspect ratio results according to the laser power calculated using the above ablation top width and ablation depth measurements. For structured electrodes, the aspect ratio of the formed groove is important because the electrode with a relatively higher aspect ratio has an increased surface area that can react electrochemically when grooves with the same width are formed. Consequently, an increase in the diffusion path of $\mathrm{L}^{+}$is favorable for the high-speed charging and discharging of the battery (Fig. 6(b) $)^{14}$. After laser irra- 

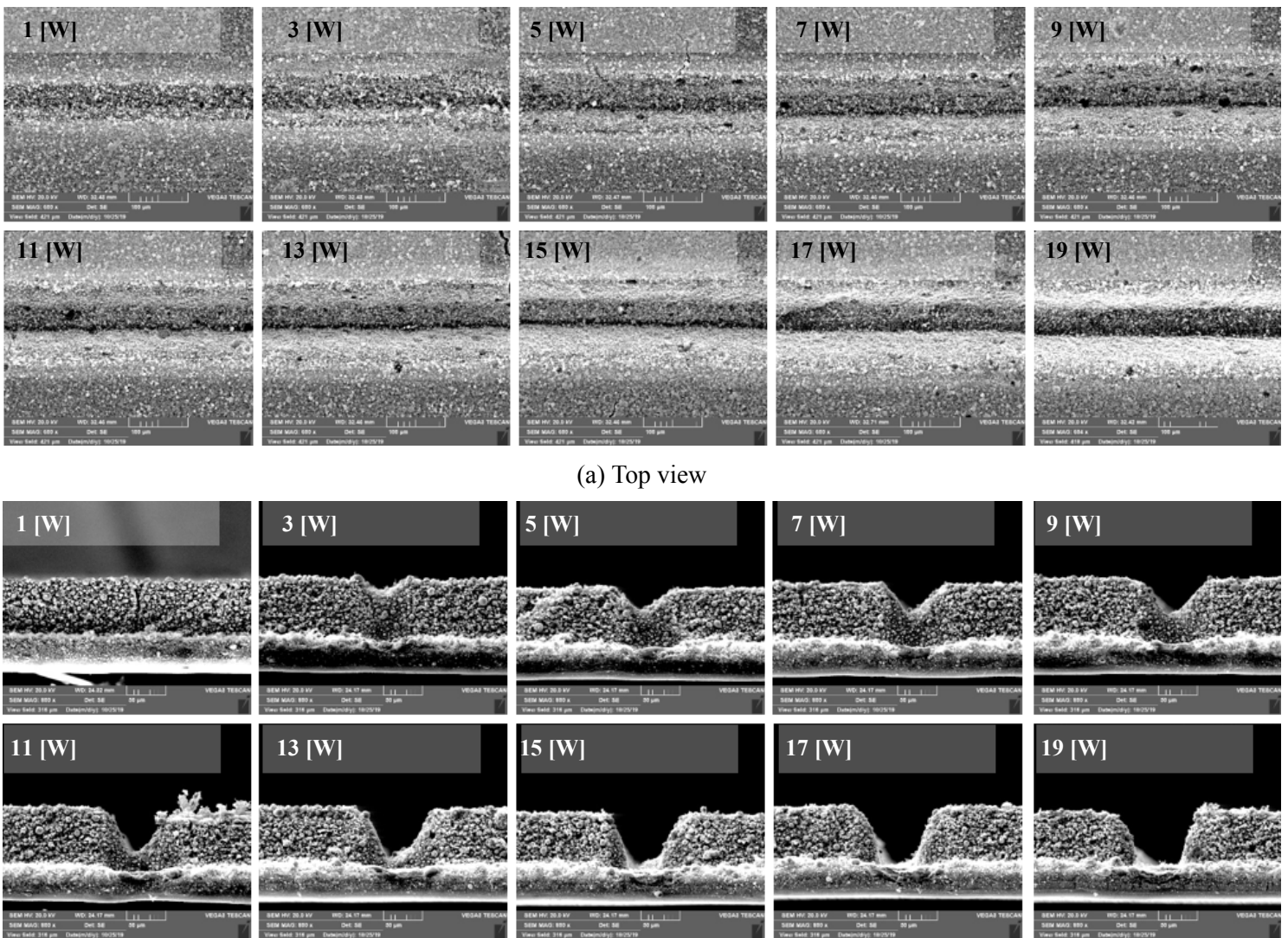

(a) Top view
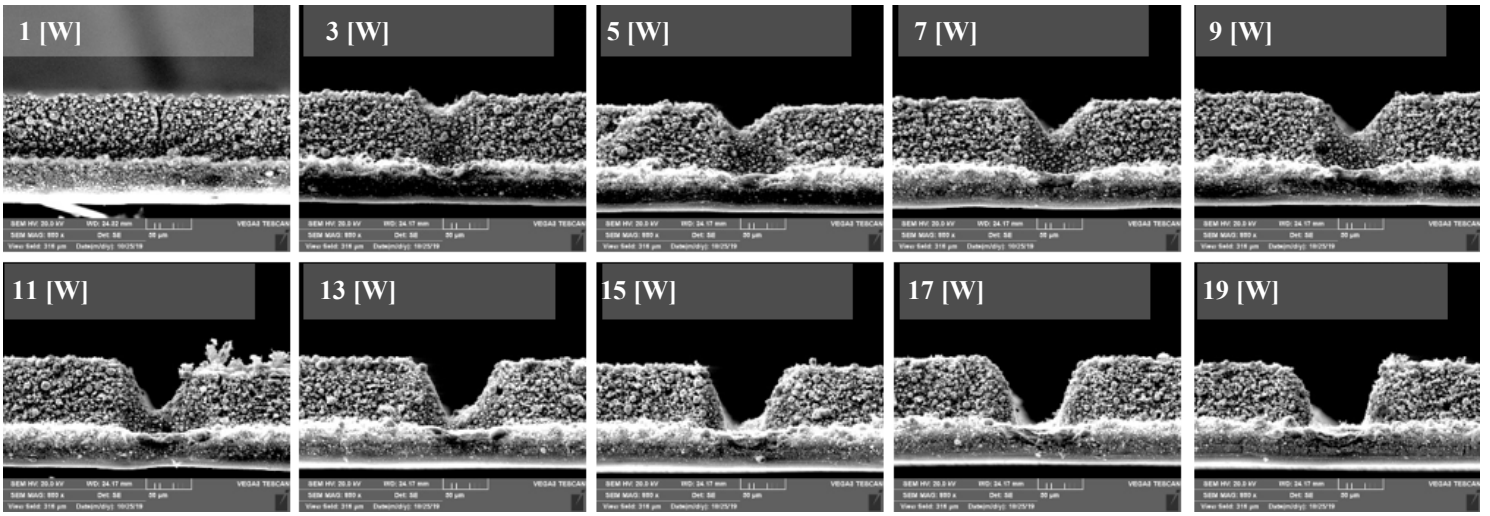

(b) Cross section view

Fig. 4 SEM image of the electrode after laser structuring in 1pass (a) Top view (b) Cross section view

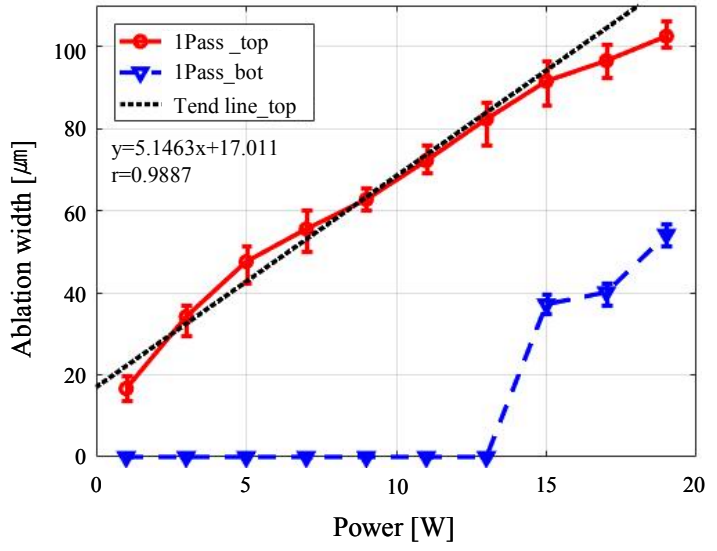

(a)

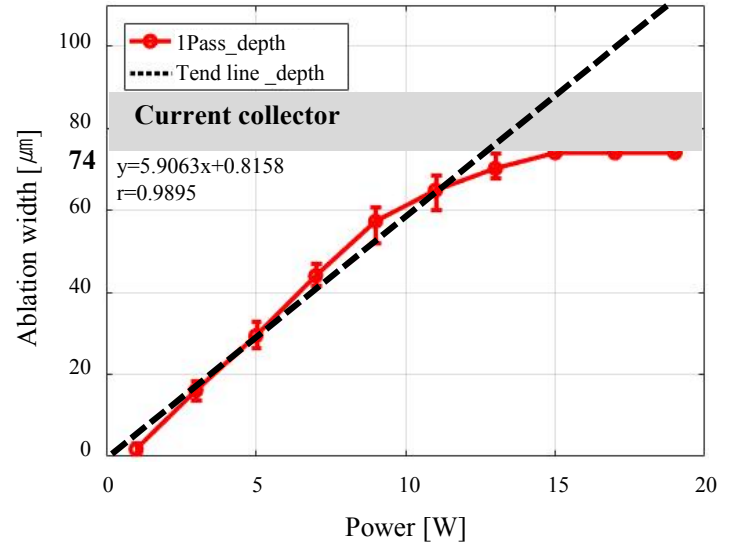

(b)

Fig. 5 (a) Ablation width and (b) ablation depth depending on power at 1pass

diation, the aspect ratio of the groove formed in the electrode sharply increased as the power increased from 1 to $11 \mathrm{~W}$, and it gradually decreased from $13 \mathrm{~W}$. This is because the ablation top width increased with almost the same slope as the power increased from 1 to $19 \mathrm{~W}$, but the ablation depth no longer increased after $13 \mathrm{~W}$ despite its relatively rapid increase when the power increased from 1 to $13 \mathrm{~W}$. In addition, the aspect ratio was highest (approximately 0.77 ) when the power was $11 \mathrm{~W}$.

\subsection{Removal amount and Removal rate of active material}

Fig. 7 shows the removal amount of active material and the active material removal rate after the laser structuring process of the electrode. The amount of the active material of the electrode is closely related to the energy density of the battery. This is because the energy density of the battery increases as the amount of the active material increases. Laser structuring of the 


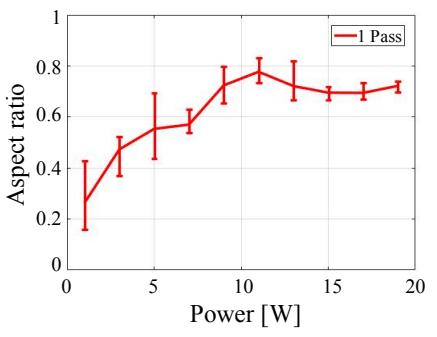

(a)

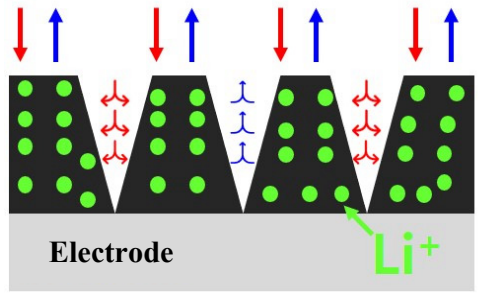

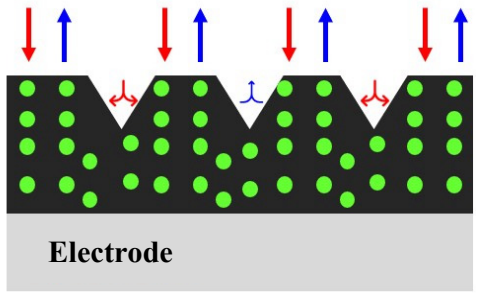

(b)

Fig. 6 (a) Aspect ratio of structured-electrodes depending on laser power and (b) comparison of Li+ diffusion path in high and low aspect ratio groove in structured-electrodes

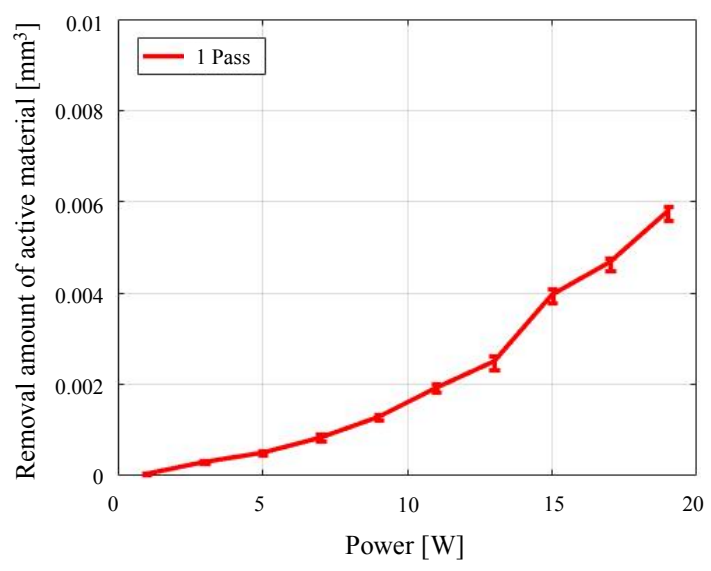

(a)

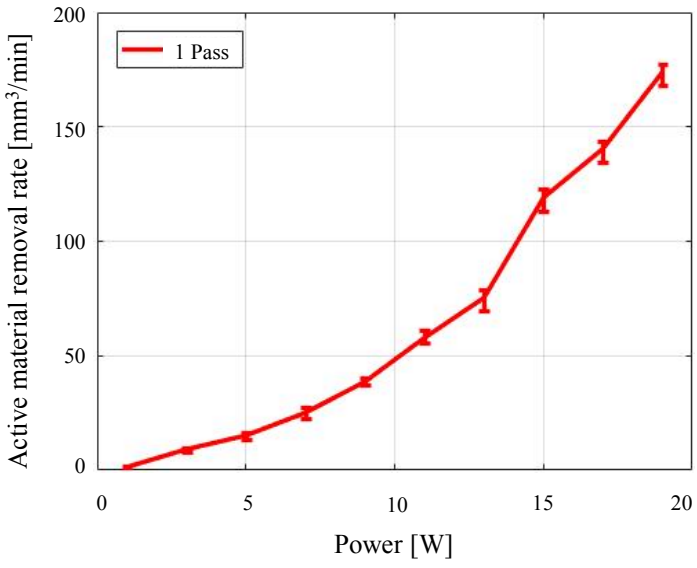

(b)

Fig. 7 (a) Removal amount and (b) removal rate of active material depending on power

electrode, however, is a method for increasing the power density by partially removing the active material and thereby causing electrochemical reaction on a larger surface. Therefore, the removal amount of active material needs to be analyzed, and further optimization is required. In addition, it is necessary to analyze the active material removal rate to determine the efficiency of the processing process. The removal amount of active material per unit volume and the removal rate per minute were calculated using equations (1) and (2).

$$
\begin{aligned}
& \text { Removal amount of active material }\left(\mathrm{mm}^{3}\right)= \\
& \quad \frac{1}{2}\left(W_{t o p}+W_{b o t}\right) \times D \times 1 \mathrm{~mm} \\
& \text { Active material removal rate }\left(\frac{\mathrm{mm}^{3}}{\mathrm{~min}}\right)= \\
& \quad \frac{1}{2}\left[\left(W_{t o p}+W_{b o t}\right) \times D\right] \times \nu
\end{aligned}
$$

The removal amount of active material per unit length ( $1 \mathrm{~mm}$ ) was calculated using the measured ablation top width $\left(W_{\text {top }}\right)$, ablation bottom width $\left(W_{\text {bot }}\right)$, and ablation depth $(D)$ as shown in equation (1). The active material removal rate was calculated using the ablation top width $\left(W_{t o p}\right)$, ablation bottom width $\left(W_{b o t}\right)$, ablation depth $(D)$, and scanning speed $(\nu)$ as shown in equation (2). Fig. 7(a) shows that the removal amount of active material increased as the laser power increased. It slowly increased as the power increased from 1 to $13 \mathrm{~W}$, and then relatively sharply increased after $15 \mathrm{~W}$. This appears to be because multiple reflections actively occurred from $15 \mathrm{~W}$ as most of the active material was removed and the laser beam reflected from the Al foil increased. Fig. 7(b) shows the active material removal rate per minute. The active material removal rate per minute increased as the laser power increased. Therefore, the efficiency of the laser structuring process increased as the laser power increased.

\section{Conclusion}

This study is a basic study on the electrode laser structuring process for high-power batteries. The electrode used in the experiment used $\mathrm{LiFePO}_{4}$ as an active material, and the possibility of the laser structuring process that uses the nanosecond laser was discussed.

1) As the laser power increased, the ablation top width and ablation bottom width increased. Under the experimental conditions, the maximum ablation top width and ablation bottom width were measured to be approx- 
imately 102 and $53 \mu \mathrm{m}$, respectively.

2) The ablation depth increased as the laser power increased, but it no longer increased after $74 \mu \mathrm{m}$ at which most of the active material was removed. In addition, the depth of the groove formed by laser processing reached the surface of the current collector, but the $\mathrm{Al}$ foil with the active material completely removed was not observed.

3) The removal amount of active material and the active material removal rate showed a tendency to increase as the laser power increased. The increase in laser power exhibited high efficiency in terms of process, but decreased the energy density of the battery by increasing the removal amount of active material in terms of battery performance.

4) The electrode laser structuring process overcomes the existing limitations of the electrode structure and improves the power density of the battery, but decreases the energy density due to the removal of the active material during the process. Therefore, appropriate laser processing parameters are required to maximize the effect of the electrode structuring process.

To verify the validity of this study, a rate capability test will be conducted by fabricating a coin cell. In addition, various processing parameters, such as the laser power, scanning speed, repetition rate, pulse duration, and number of passes, will be analyzed for the optimization of the electrode laser structuring process.

\section{Acknowledgment}

The research described herein was sponsored by the National Research Foundation of Korea (NRF) grant funded by the Korean government (MSIP; Ministry of Science, ICT \& Future planning) (No. 2019R1A2C1089644). The opinions expressed in this paper is those of the authors and do not necessarily reflect the views of the sponsors.

ORCID: Dongkyu Park: https://orcid.org/0000-0002-2535-2593

ORCID: Dongkyoung Lee: https://orcid.org/0000-0001-9404-2321

\section{Reference}

1. W. Pfleging, A review of laser electrode processing for development and manufacturing of lithium-ion batteries, Nanophotonics, (2017) 1-25. http://doi.org/10.1515/nanoph-2017-0044

2. W. J. Zhang, Structure and performance of $\mathrm{LiFePO}_{4}$ cathode materials: A review, J. Power Sources, 196(6) (2011) 2962-2970.

http://doi.org/10.1016/j.jpowsour.2010.11.113
3. Y. Li, J. Wang, H. X. Huang, J. Wang, M. Zhang, and Mm. M. Liang, Co-coating effect of GdPO4 and carbon on $\mathrm{LiFePO}_{4}$ cathode surface for lithium ion batteries, Adv. Powder Technol., 30(8) (2019) 1442-1449. http://doi.org/10.1016/j.apt.2019.04.017

4. D. Lee, B. Oh, and J. Suk, The effect of compactness on laser cutting of cathode for Lithium-Ion Batteries using continuous fiber laser, Appl. Sci., 9(1) (2019). http://doi.org/10.1016/j.jpowsour.2014.04.127

5. Y. Seo, D. Lee, and S. Pyo, Microstructural characteristics of cement-based materials fabricated using multimode fiber laser, Materials (Basel)., 13(3) (2020) 1-10. http://doi.org/10.3390/ma13030546

6. Y. Seo, D. Lee, and S. Pyo, High-power fiber laser cutting for 50-mm-thick cement-based materials, Materials, 13(5),1113 (2020). http://doi.org/10.3390/ma13051113

7. D. Lee, Y. Seo, and S. Pyo, Effect of laser speed on cutting characteristics of cement-based materials, Materials (Basel)., 11(7) (2018). http://doi.org/10.3390/ma11071055

8. D. Lee, Experimental Investigation of Laser Spot Welding of Ni and Au-Sn-Ni Alloy, J. Weld. Join., 35(2) (2017) $1-5$. http://doi.org/10.5781/JWJ.2017.35.2.1

9. R. Kohler, M. Bruns, P. Smyrek, S. Ulrich, M. Przybylski, and W. Pfleging, Laser annealing of textured thin film cathode material for lithium ion batteries, Laser-based Micro-Nanopackaging Assem. IV 7585 (2010) $75850 \mathrm{O}$. http://doi.org/10.1117/12.841259

10. Y. Zhang, J. Li, R. Yang, T. Liu, and Y. Yan, Analysis of kerf quality on ultrafast laser cutting of anode material for lithium-ion battery, Opt. Lasers Eng., vol. 118, no. January, (2019) 14-21. http://doi.org/10.1016/j.optlaseng.2019.01.013

11. D. Lee and J. Mazumder, Effects of momentum transfer on sizing of current collectors for lithium-ion batteries during laser cutting, Opt. Laser Technol., 99 (2018) 315-325. http://doi.org/10.1016/j.optlastec.2017.09.016

12. A. H. A. Lutey, A. Fortunato, S. Carmignato, and M. Fiorini, High speed pulsed laser cutting of Li-ion battery electrodes, Opt. Laser Technol., 94 (2017) 90-96. http://doi.org/10.1016/j.optlastec.2017.03.022

13. D. Lee and S. Ahn, Investigation of Laser Cutting Width of LiCoO2 Coated Aluminum for Lithium-Ion Batteries, Appl. Sci., 7(9) (2017) 914. http://doi.org/10.3390/app7090914

14. M. Mangang, H. J. Seifert, and W. Pfleging, Influence of laser pulse duration on the electrochemical performance of laser structured $\mathrm{LiFePO}_{4}$ composite electrodes, J. Power Sources, 304 (2016) 24-32. http://doi.org/10.1016/j.jpowsour.2015.10.086 


\title{
리튬이온 배터리 성능 향상을 위한 나노초 레이저를 이용한 전극의 구조화 실험적 연구
}

\author{
Experimental Study of Electrode Structuring using Nanosecond Laser \\ for Enhanced Battery Performance
}

\author{
박 동 규 ${ }^{*}$ 이 동 경* \\ *공주대학교 기계자동차공학부
}

\section{1. 서 론}

현재 리튬이온 배터리는(Lithium-ion battery)는 가벼운 중량, 높은 에너지밀도, 높은 출력밀도, 긴 사이 클 수명의 장점이 있어, 환경오염 및 화석연료의 고갈 문제의 해결책으로 관심이 높아지고 있다. 리튬이온 배터 리는 cathode, anode, electrolyte, separator로 구 성되어 있다. 특히, cathode와 anode는 배터리의 에 너지 밀도 및 출력 밀도를 결정하는 중요한 요소이다 ${ }^{1,2)}$. 따라서, 전극제조공정에서 배터리 성능 향상 및 기 존의 배터리 가공공정의 문제점을 개선하기 위하여 많 은 연구가 진행되고 있다. 배터리 성능 향상 관련 연구 에서 $\mathrm{Li}$ 등 3$)$ 은 $\mathrm{LiFePO}_{4}$ 에 Carbon과 $\mathrm{GdPO} 4$ 의 코팅 층을 형성하여 이온 확산 속도를 증가시켜 출력밀도를 높였다. 한편, 기존의 전극 절단 공정의 단점을 보완하 기 위하여 Lee 등ㄴ)은 레이저를 사용하여 전극을 절단 하였으며, 압축전극과 비압축전극의 절단특성을 비교하 였고 레이저를 이용하여 전극을 절단할 때 압축된 전극 이 균일한 절단폭을 얻기 유리하다는 것을 제시하였다.

최근 절단, 용접, 열처리, 표면가공 등 많은 공정들이 레이저로 성공적으로 대체되고 있다 ${ }^{5,9)}$. 레이저는 비 접촉식 가공으로 유지보수비용이 적으며, 가공물의 오 염을 줄일 수 있다. 그리고 micro-scale의 가공이 가 능하며, 복잡한 형상의 가공도 쉽게 할 수 있다. 게다 가 플라스틱, 유리 및 박막 등 민감한 재료도 변형을 최소화하여 가공할 수 있다 ${ }^{10,13)}$.

본 연구에서 배터리의 출력밀도를 향상시키기 위하여 레이저를 이용한 전극구조화를 진행하였다. 기존의 전 극 구조의 문제점은 에너지밀도를 증가시키기 위해 활 물질을 두껍게 코팅하면 출력밀도가 감소하며, 반대로 출력밀도를 높이기 위해 활물질을 얇게 코팅하면 에너 지밀도가 낮아 배터리가 빠르게 방전된다. 이러한 전극
구조의 한계를 극복하기 위하여 3 차원 형태의 전극이 제시되고 있다. 선행된 연구에서 $\mathrm{LiFePO}_{4}$ 전극에 femtosecond-laser, picosecond-laser, nanosecond-laser를 각각 사용하여 레이저 구조화(laser structuring)을 진행 하여 형성된 groove 및 배터리 성능을 비교하였다 ${ }^{14)}$. Pulse duration이 짧을수록 구조화된 전극의 홈(groove) 의 aspect ratio가 증가하였다. 또한 aspect ratio가 증가할수록 배터리 성능테스트에서 출력밀도가 증가하는 것 을 보고하였다. 하지만, 선행된 연구에선 pulse duration에 대한 영향만 관찰하였으며, 레이저 출력에 따른 변화에 대한 정보는 부족하다. 그리고, 열영향이 적으며, 선택적 으로 재료를 제거하기 유리한 femtosecond-laser는 여전 히 고가의 장비이다 ${ }^{10)}$. 따라서, 본 연구는 femtosecondlaser 보다 투자비용이 적은 nanosecond-laser를 이용 하여 전극표면에 기하학적 형상을 가공하여 고출력 배터 리를 제작하기 위한 기초연구이다. Nano-second-laser 를 이용하여 레이저 출력에 따른 영향을 ablation width, ablation depth, aspect ratio를 통해 관찰하였다. 또 한, 활물질(active material)의 제거량과 활물질의 제거 율을 분석하였다.

\section{2. 실험재료 및 실험방법}

\section{1 전극제작}

Fig. 1는 실험에 사용된 전극의 사진과 절단면을 모 식도로 표현하였다. 실험에 사용된 전극은 실내 온도 $20{ }^{\circ} \mathrm{C}$ 와 이슬점(Dew Point) $-40{ }^{\circ} \mathrm{C}$ 이하로 유지되 는 dry room 안에서 제작됐다. Table 1은 실험에 사 용된 전극의 자세한 정보를 나타냈다. 전극에 사용된 slurry는 $\mathrm{LiFePO}_{4}$ (active material)와 Polyvinylidene Fluoride (Binder)과 Super P (Conducting agent)를 질량분율 $8: 1: 1$ 로 섞어 제작되었다. 제 

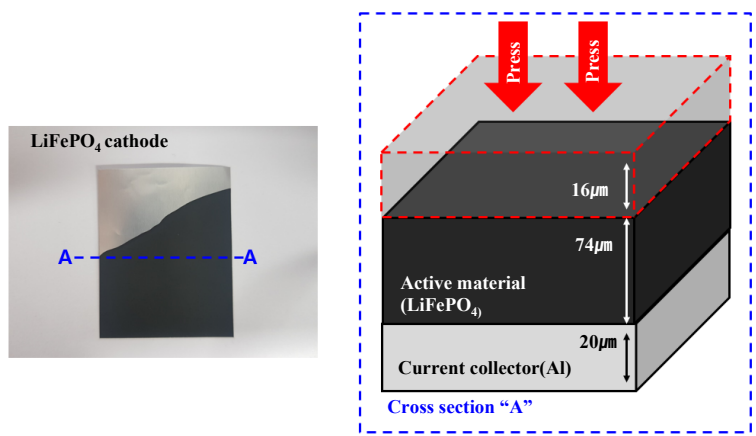

Fig. 1 Image of electrode used for the experiments

Table 1 Information of electrode used for the experiments

\begin{tabular}{|c|c|}
\hline Classification & Information \\
\hline Structure & One-side sandwich \\
\hline Active material & $\mathrm{LiFePO}_{4}(8)$ \\
\hline Binder & Polyvinylidene fluoride (1) $^{\text {Super } \mathrm{P}(1)}$ \\
\hline Conducting agent & $90 \mu \mathrm{m} \rightarrow 74 \mu \mathrm{m}$ \\
\hline Active electrode thickness & Aluminum Foil \\
\hline Current collector & $20 \mu \mathrm{m}$ \\
\hline Current collector thickness & \\
\hline
\end{tabular}

작된 slurry는 $20 \mu \mathrm{m}$ aluminum foil에 $90 \mu \mathrm{m}$ 의 두께 로 한쪽 면만 코팅되어 One-side sandwich 구조의 전극을 만들었다. 그리고 오븐에서 $120{ }^{\circ} \mathrm{C}$ 에서 2 시간 동안 1차 건조를 한 뒤, Calendaring을 진행하여 전 극을 압축하여 총 $94 \mu \mathrm{m}$ 두께의 전극을 제작하였다. 마 지막으로 $120{ }^{\circ} \mathrm{C}$ 에서 24 시간동안 2 차 건조를 했다.

\section{2 레이저 가공}

전극을 구조화하기 위하여 사용된 Ytterbium Pulsed Fiber Laser (YLPM-1-4×200-20-20, IPG)의 max average power는 $20 \mathrm{~W}$ 이며 $1064 \mathrm{~nm}$ 의 파장을 갖고 있다. 또한 $4 \mathrm{~ns} \sim 200 \mathrm{~ns}$ 까지 pulse duration을 가
Table 2 Laser parameters used for the experiments

\begin{tabular}{|c|c|}
\hline Parameters & Specifications \\
\hline Average power & $1 \sim 19 \mathrm{~W}$ \\
\hline Mode & Pulsed laser \\
\hline Wavelength & $1064 \mathrm{~nm}$ \\
\hline Pulse duration & $4 \mathrm{~ns}$ \\
\hline Pulse repetition rate & $500 \mathrm{kHz}$ \\
\hline Scanning speed & $500 \mathrm{~mm} / \mathrm{s}$ \\
\hline Focal length & $189 \mathrm{~mm}$ \\
\hline Spot size & Approx. $30 \mu \mathrm{m}$ \\
\hline Beam quality (M2) & 1.5 \\
\hline
\end{tabular}

변 할 수 있는 장점이 있다. 그리고 1.5 의 $\mathrm{M}^{2}$ 값을 갖 고 있다. 본 실험은 다양한 레이저 가공변수 중 오직 average power만 변경하여 실험을 단순화하여 진행하 였다. Average power는 $1 \mathrm{~W} \sim 19 \mathrm{~W}$ 까지 $2 \mathrm{~W}$ 간격 으로 조사하였다.

\section{3 분석 방법}

Fig. 3는 전극에 레이저 조사 후 주사주사현미경 $(\mathrm{SEM})$ 으로 촬영한 사진이며, 전극의 기하학적 변화를

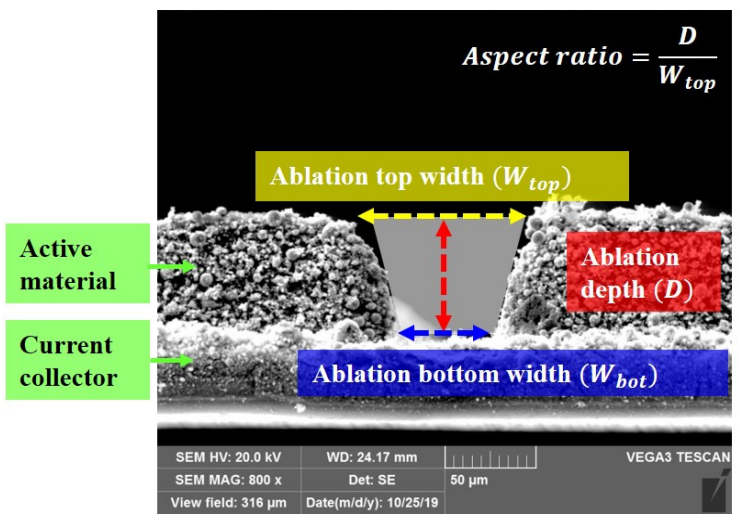

Fig. 3 Measurement method of the ablation top width, ablation bottom width, ablation depth

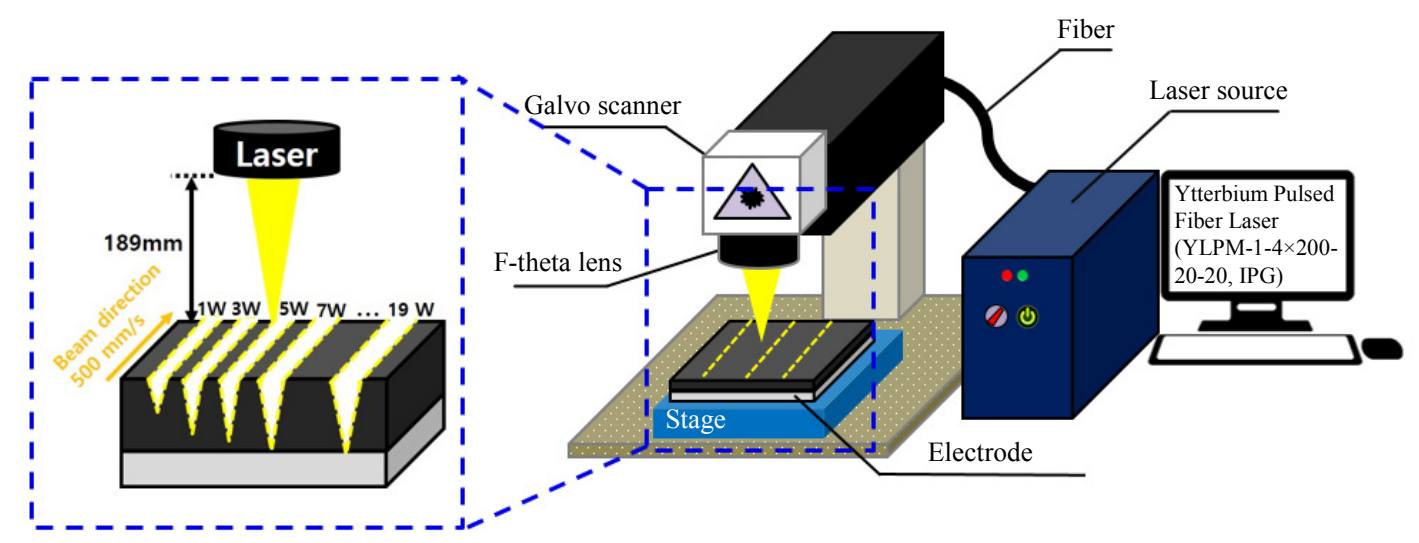

Fig. 2 Schematic of the nanosecond laser for laser structuring of electrode 
분석하기 위하여 ablation top width $\left(W_{\text {top }}\right)$, ablation bottom width $\left(W_{b o t}\right)$, ablation $\operatorname{depth}(\mathrm{D})$ 를 정의하 였다. Ablation top width는 전극의 레이저 가공 후 에 활물질이 제거되어 형성된 상단 폭(width) 이다. Ablation bottom width는 전극의 laser 가공 후 활물 질이 제거되어 형성된 하단 폭이며, ablation depth는 레이저 가공 후 활물질이 제거되어 형성된 홈의 깊이 (depth)를 측정하였다. Aspect ratio는 측정된 ablation top width $\left(W_{\text {top }}\right)$ 와 ablation $\operatorname{depth}(\mathrm{D})$ 를 이용하여 계산되었다.

\section{3. 실험결과 및 고찰}

\subsection{Ablation width and Ablation depth}

Fig. 4는 레이저 구조화 가공 후 전극을 전자주사현 미경 $(\mathrm{SEM})$ 을 통해 관찰한 사진이다. Fig. 4를 보면, 레이저 출력이 증가할수록 ablation width와 ablation $\operatorname{depth}(\mathrm{D})$ 모두 증가한 것을 관찰할 수 있다. Top view (Fig. 4(a))에서 출력이 증가함에 따라 활물질층에 생 긴 홈의 깊이가 증가하여 집전장치(current collector) 의 표면까지 형성되었지만, 활물질이 완전히 제거된 alumium foil은 관찰되지 않았다. Fig. 5는 레이저 파워에 따른 ablation width와 ablation depth의 측 정값이다. Fig. 5(a)를 보면, ablation top width는 레이저 출력이 증가함에 따라 선형적으로 증가하였다. 그리고 $19 \mathrm{~W}$ 에서 약 $102 \mu \mathrm{m}$ 로 가장 넓게 형성되었다. 반면, ablation bottom width는 $13 \mathrm{~W}$ 까지 형성되지 않았으며, $15 \mathrm{~W}$ 부터 활물질이 대부분 제거되면서 ablation bottom width가 형성되었다. Fig. 5(b)에 서 ablation depth는 레이저 출력이 증가함에 따라 선 형적으로 증가하였다. 또한, ablation top width와 비 교하여 가파르게 증가하였으며, 코팅된 활물질이 집전장 치의 표면까지 제거된 이후에 더 이상 증가하지 않았다. 더 정확한 비교를 위하여 회귀분석을 통하여 ablation top width와 ablation depth의 추세선과 상관계수 (r)를 계산하였다. 레이저 출력 $13 \mathrm{~W}$ 이후부터 활물질 이 완전히 제거되어 더 이상 증가하지 않아 회귀분석은 활물질이 완전히 제거되기 전까지 데이터만 사용하였다. Fig. 5 를 보면, ablation top width의 추세선의 기울기 는 5.1643이고, ablation depth의 추세선의 기울기는 5.9063으로 ablation depth의 기울기가 상대적으로 가파르게 증가하였다.
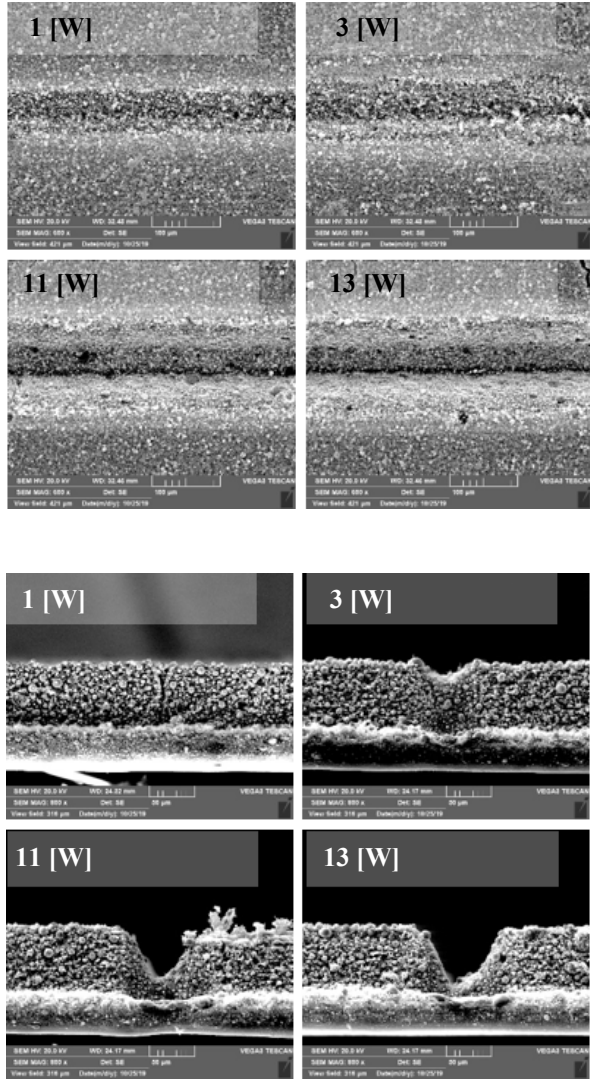

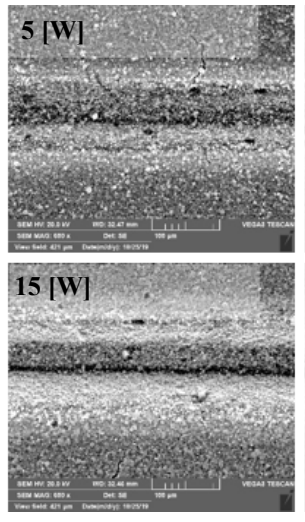

(a) Top view

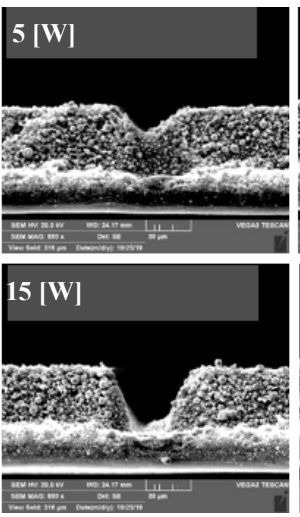

(b) Cross section view
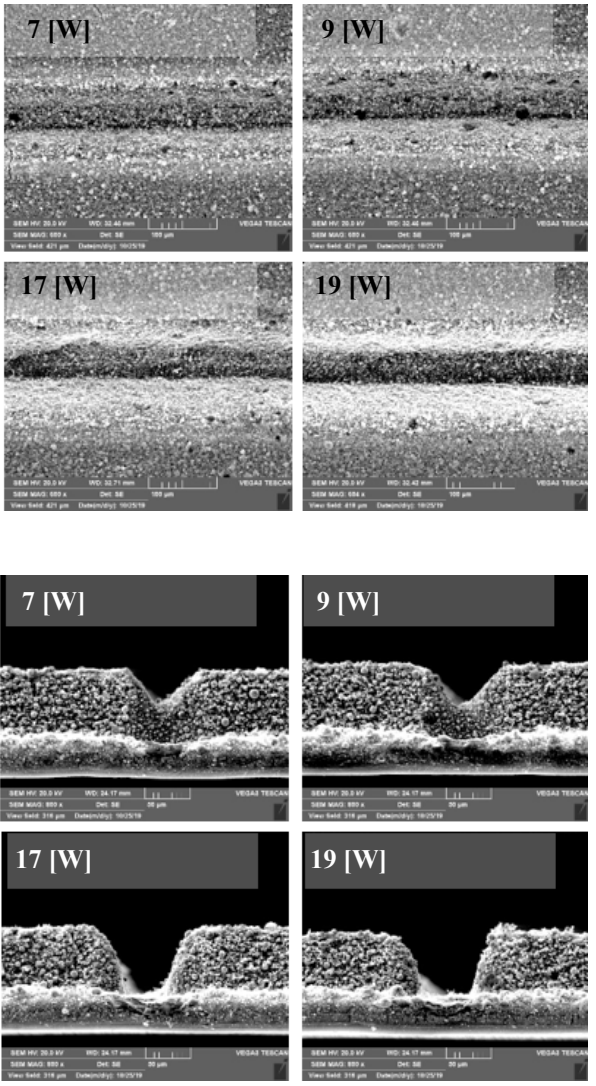

Fig. 4 SEM image of the electrode after laser structuring in 1pass (a) Top view (b) Cross section view 


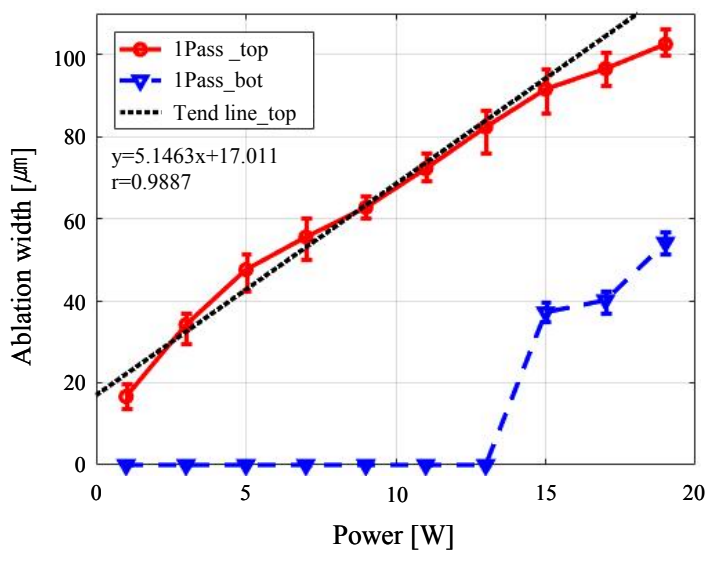

(a)

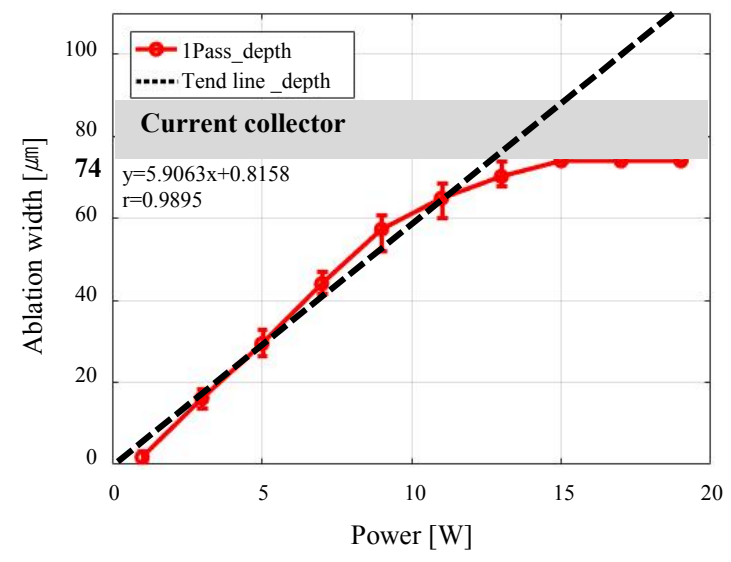

(b)

Fig. 5 (a) Ablation width and (b) ablation depth depending on power at 1 pass

\subsection{Aspect ratio}

Fig. 6(a) 앞서 측정된 ablation top width와 ablation depth를 통해 계산된 aspect ratio를 레이 저 출력에 따라 나타냈다. 구조화된 전극에서 형성된 홈 의 aspect ratio가 중요한 이유는 동일한 폭의 groove 가 형성되었을 때, 상대적으로 높은 aspect ratio가 형 성된 전극은 전기화학적으로 반응할 수 있는 표면적이 증가된다. 결과적으로 $\mathrm{L}^{+}$의 확산경로 증가는 배터리의 고 속 충·방전에 유리하기 때문이다(Fig. 6(b) $)^{14)}$. 레이저 조사 후 전극에 형성된 홈의 aspect ratio는 $1 \mathrm{~W} 11 \mathrm{~W}$ 까 지 급격하게 증가하였고 $13 \mathrm{~W}$ 부터 완만하게 감소하였다. 이러한 이유는 ablation top width는 $1 \mathrm{~W} \sim 19 \mathrm{~W}$ 까지 거의 동일한 기울기로 증가하는 반면 ablation depth는 $1 \mathrm{~W} \sim 13 \mathrm{~W}$ 까지 상대적으로 급격하게 증가되지만 $13 \mathrm{~W}$ 이후 더 이상 증가되지 않았기 때문이다. 또한, aspect ratio는 $11 \mathrm{~W}$ 에서 약 0.77 로 가장 높았다.

\section{3 활물질의 제거량과 제거율}

Fig. 7는 전극의 레이저 구조화 공정 후에 활물질 제 거량(removal amount of active material)과 활물
질 제거율(active material removal rate)이다. 전극 의 활물질의 양은 배터리의 에너지밀도와 밀접한 관계 가 있다. 예를 들어, 활물질의 양이 증가할수록 배터리 의 에너지밀도가 증가하기 때문이다. 그러나, 전극의 레이저 구조화는 활물질을 부분적으로 제거하여 전기화 학적 반응을 보다 넓은 표면에서 발생시켜 출력밀도를 높이는 방법이다. 따라서 활물질 제거량에 대한 분석이 필요하며, 더 나아가 최적화가 필요하다. 또한, 활물질 제거율는 가공공정의 효율성을 판단하기 위해 분석이 필요하다. 단위 부피 당 활물질 제거량과 분당 제거율 은 각각 eq. (1) 과 eq. (2)을 통해 계산하였다.

Removal amount of active material $\left(\mathrm{mm}^{3}\right)=$

$$
\frac{1}{2}\left(W_{\text {top }}+W_{b o t}\right) \times D \times 1 m m
$$

Active material removal rate $\left(\frac{\mathrm{mm}^{3}}{\mathrm{~min}}\right)=$

$$
\frac{1}{2}\left[\left(W_{t o p}+W_{b o t}\right) \times D\right] \times \nu
$$

활물질 제거량은 Eq. (1)과 같이 측정된 ablation top width $\left(W_{t o p}\right)$, ablation bottom width $\left(W_{b o t}\right)$ 와 ablation $\operatorname{depth}(D)$ 를 이용하여 계산하였으며, 단위길이 $(1 \mathrm{~mm})$

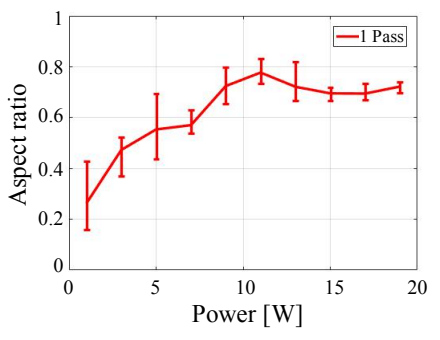

(a)

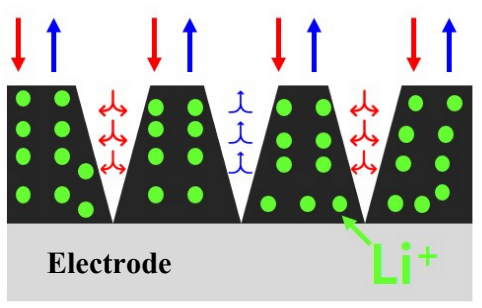

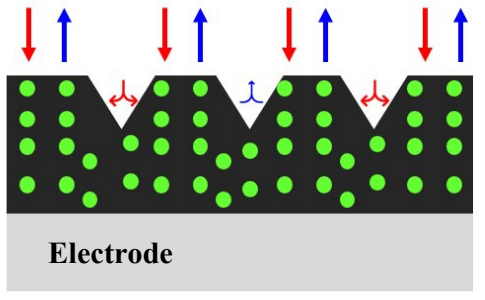

(b)

Fig. 6 (a) Aspect ratio of structured-electrodes depending on laser power and (b) comparison of Li+ diffusion path in high and low aspect ratio groove in structured-electrodes 


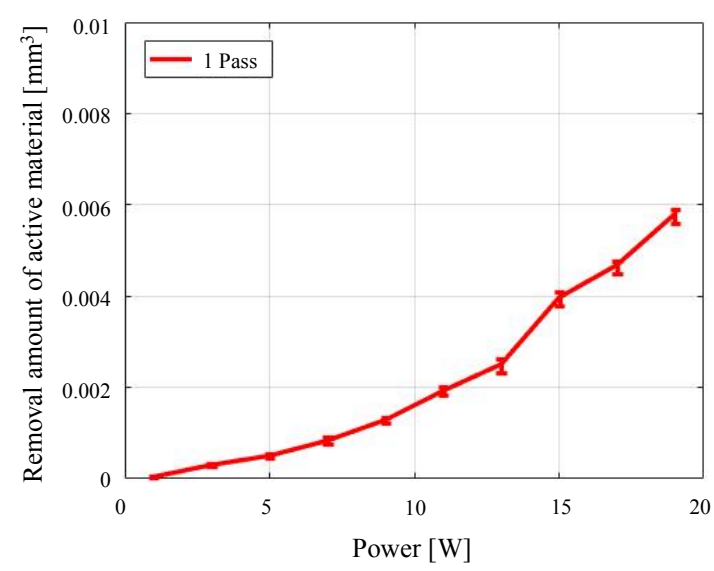

(a)

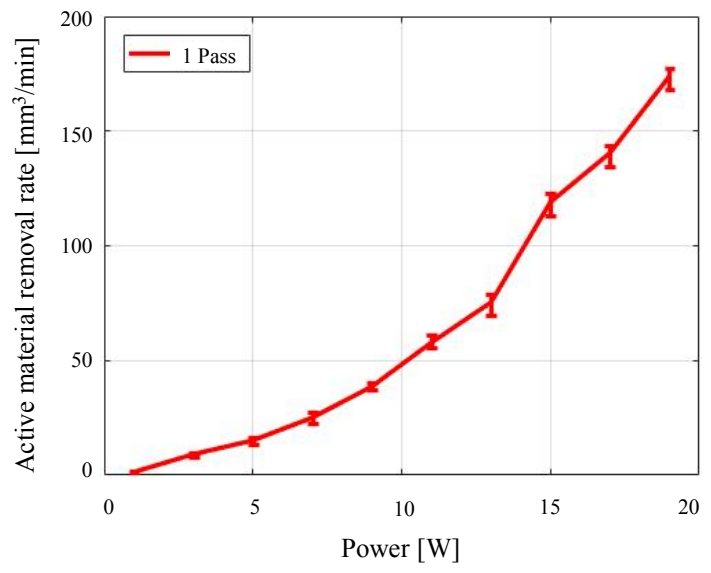

(b)

Fig. 7 (a) Removal amount and (b) removal rate of active material depending on power

당 제거량으로 나타냈다. 활물질 제거율은 Eq. (2)를 통 해 계산되었으며, ablation top width $\left(W_{\text {top }}\right)$, ablation $\operatorname{bottom} \operatorname{width}\left(W_{\text {bot }}\right)$, ablation $\operatorname{depth}(D)$, 그리고 조 사속도 $(\nu)$ 를 사용하였다. Fig. 7 (a)를 보면 활물질 제 거량은 레이저 출력이 증가할수록 증가하였다. $1 \mathrm{~W}$ $13 \mathrm{~W}$ 까지 완만하게 증가하며 $15 \mathrm{~W}$ 이후 비교적 급격 히 증가하였다. 이러한 현상은 $15 \mathrm{~W}$ 부터 활물질이 대 부분 제거되어 aluminum foil에 반사된 레이저 빔이 증가하여 다중반사가 활발히 일어나 ablation width가 증가한 것으로 추측된다. Fig. 7 (b)는 분당 재료가 제 거된 재료 제거율을 보여주며, 레이저 출력이 증가할수 록 활물질 분당 재료 제거율은 증가한다. 따라서, 레이 저 출력이 증가할수록 레이저 구조화 가공 효율이 증가 된다.

\section{4. 결 론}

본 연구는 고출력 배터리를 위한 전극 laser structuring 가공의 기초 연구이다. 실험에 사용된 전극은 $\mathrm{LiFePO}_{4}$ 를 활물질로 사용했으며, 나노초 레이저를 이용한 레이 저 구조화 공정의 가능성에 대해 논의하였다.

1) 레이저 출력이 증가함에 따라 ablation top width 와 ablation bottom width는 증가하였으며, 실험 조건 내에서 ablation top width와 ablation bottom width 는 각각 최대 약 $102 \mu \mathrm{m}$, 약 $53 \mu \mathrm{m}$ 으로 측정되었다.

2) Ablation depth는 레이저 출력이 증가할수록 증 가하였으며, 활물질이 대부분 제거된 $74 \mu \mathrm{m}$ 이후 증가되 지 않았다. 또한, 레이저 가공 후 형성된 홈이 집전장 치 표면까지 형성되었지만, 활물질이 완전히 제거된 aluminum foil은 관찰되지 않았다.

3) 활물질 제거량과 활물질 제거율은 레이저 출력이 증 가함에 따라 증가하는 경향이 있다. 레이저 출력의 증
가는 공정측면에서 좋은 효율을 보여주지만 배터리 성 능측면에서 활물질 제거량이 증가하여 배터리의 에너지 밀도를 감소시킨다.

4) 전극의 레이저 구조화 공정은 기존의 전극 구조의 한계를 극복하여 배터리의 출력밀도를 향상시키지만 공 정 중 제거되는 활물질로 인하여 에너지 밀도를 감소시 키므로 전극구조화 공정의 효과를 극대화하기 위해 적 절한 레이저 가공변수가 필요하다.

본 연구의 유효성을 검증하기위해 코인 셀을 제작하 여 rate capability test가 진행될 계획이며, 전극의 레 이저구조화 공정의 최적화를 달성하기 위하여 레이저 출 력뿐만 아니라 조사속도(scanning speed), 반복률(repetition rate), 펄스 폭(pulse duration), 조사 횟수(the number of pass) 등 다양한 가공변수에 대한 분석을 진행할 계획이다.

\section{Acknowledgment}

The research described herein was sponsored by the National Research Foundation of Korea (NRF) grant funded by the Korean government (MSIP; Ministry of Science, ICT \& Future planning) (No. 2019R1A2C1089644). The opinions expressed in this paper is those of the authors and do not necessarily reflect the views of the sponsors.

ORCID: Dongkyu Park: https://orcid.org/0000-0002-2535-2593 ORCID: Dongkyoung Lee: https://orcid.org/0000-0001-9404-2321

\section{Reference}

1. W. Pfleging, A review of laser electrode processing for development and manufacturing of lithium-ion batteries, Nanophotonics, (2017) 1-25. 
http://doi.org/10.1515/nanoph-2017-0044

2. W. J. Zhang, Structure and performance of $\mathrm{LiFePO}_{4}$ cathode materials: A review, J. Power Sources, 196(6) (2011) 2962-2970. http://doi.org/10.1016/j.jpowsour.2010.11.113

3. Y. Li, J. Wang, H. X. Huang, J. Wang, M. Zhang, and $\mathrm{Mm}$. M. Liang, Co-coating effect of GdPO4 and carbon on $\mathrm{LiFePO}_{4}$ cathode surface for lithium ion batteries, Adv. Powder Technol., 30(8) (2019) 1442-1449. http://doi.org/10.1016/j.apt.2019.04.017

4. D. Lee, B. Oh, and J. Suk, The effect of compactness on laser cutting of cathode for Lithium-Ion Batteries using continuous fiber laser, Appl. Sci., 9(1) (2019). http://doi.org/10.1016/j.jpowsour.2014.04.127

5. Y. Seo, D. Lee, and S. Pyo, Microstructural characteristics of cement-based materials fabricated using multimode fiber laser, Materials (Basel)., 13(3) (2020) 1-10. http://doi.org/10.3390/ma13030546

6. Y. Seo, D. Lee, and S. Pyo, High-power fiber laser cutting for 50-mm-thick cement-based materials, Materials, 13(5), 1113 (2020). http://doi.org/10.3390/ma13051113

7. D. Lee, Y. Seo, and S. Pyo, Effect of laser speed on cutting characteristics of cement-based materials, Materials (Basel)., 11(7) (2018). http://doi.org/10.3390/ma11071055

8. D. Lee, Experimental Investigation of Laser Spot Welding of Ni and Au-Sn-Ni Alloy, J. Weld. Join., 35(2) (2017) 1-5. http://doi.org/10.5781/JWJ.2017.35.2.1
9. R. Kohler, M. Bruns, P. Smyrek, S. Ulrich, M. Przybylski, and W. Pfleging, Laser annealing of textured thin film cathode material for lithium ion batteries, Laser-based Micro-Nanopackaging Assem. IV, 7585 (2010) 758500. http://doi.org/10.1117/12.841259

10. Y. Zhang, J. Li, R. Yang, T. Liu, and Y. Yan, Analysis of kerf quality on ultrafast laser cutting of anode material for lithium-ion battery, Opt. Lasers Eng., vol. 118, no. January, (2019) 14-21.

http://doi.org/10.1016/j.optlaseng.2019.01.013

11. D. Lee and J. Mazumder, Effects of momentum transfer on sizing of current collectors for lithium-ion batteries during laser cutting, Opt. Laser Technol., 99 (2018) 315-325. http://doi.org/10.1016/j.optlastec.2017.09.016

12. A. H. A. Lutey, A. Fortunato, S. Carmignato, and M. Fiorini, High speed pulsed laser cutting of Li-ion battery electrodes, Opt. Laser Technol., 94 (2017) 90-96. http://doi.org/10.1016/j.optlastec.2017.03.022

13. D. Lee and S. Ahn, Investigation of Laser Cutting Width of LiCoO2 Coated Aluminum for Lithium-Ion Batteries, Appl. Sci., 7(9) (2017) 914. http://doi.org/10.3390/app7090914

14. M. Mangang, H. J. Seifert, and W. Pfleging, Influence of laser pulse duration on the electrochemical performance of laser structured $\mathrm{LiFePO}_{4}$ composite electrodes, J. Power Sources, 304 (2016) 24-32. http://doi.org/10.1016/j.jpowsour.2015.10.086 